\title{
PERSEPSI DAN SIKAP PELAJAR TERHADAP REKA BENTUK DAN SUSUNATUR KEDAI DI KOPERASI POLITEKNIK SULTAN ABDUL HALIM MU'ADZAM SHAH (POLIMAS)
}

Nor Syuhani Shaari dan Norazlizah Saad

\author{
Jabatan Perdagangan, Politeknik Sultan Abdul Halim Mu'adzam Shah, Kedah, Malaysia
}

\begin{abstract}
Abstrak: Persekitaran fizikal dan susun atur barang niaga boleh mempengaruhi kecenderungan pembelian pengguna dan membantu meningkatkan jualan peruncit. Justeru, penyelidik ingin meninjau sikap dan persepsi pelajar terhadap rekabentuk fizikal dan susunatur barangniaga di koperasi Polimas. Reka bentuk fizikal dan susun atur yang digunakan berperanan penting dalam menarik minat pelajar membuat pembelian dan boleh meningkatkan kunjungan pelajar ke koperasi. Kajian ini bertujuan meninjau persepsi dan sikap pengguna terhadap rekabentuk dan susunatur barangniaga, mengenalpasti permasalahan yang dihadapi oleh pelajar semasa membeli di koperasi Polimas dan mengenalpasti aspekaspek rekabentuk dan susunatur barangniaga koperasi yang perlu dilakukan penambahbaikan pada masa hadapan. Pengkaji memilih kaedah diskriptif dalam menjalankan penyelidikan dan mengedarkan borang soal-selidik kepada 150 orang responden yang terdiri daripada pelajar semester 4 Jabatan Perdagangan menggunakan persampelan mudah. Hasil analisis menunjukkan kebanyakan pelajar kurang menyukai susunatur dalaman kedai kerana bagi mereka ianya kurang menarik perhatian, kurang kreatif dan cantik. Rata-rata pelajar bersetuju bahawa penambahbaikan dari segi rekabentuk dan susunatur amat perlu dilakukan oleh pihak pengurusan koperasi. Kajian ini hanya memfokus kepada persepsi dan sikap pelajar terhadap rekabentuk dan susunatur kedai. Dicadangkan penyelidik pada masa hadapan melakukan kajian ke atas impak rekabentuk dan susunatur kedai ke atas kepuasan pelanggan ataupun jualan.
\end{abstract}

Katakunci : Rekabentuk kedai, susunatur kedai, persepsi, sikap

\section{PENDAHULUAN}

Rekabentuk kedai dan susun atur barangniaga adalah satu cara yang digunakan oleh peruncit untuk memperagakan barangan yang dijual supaya boleh dilihat pelanggan. Elemen-elemen yang kerap digunakan dalam rekabentuk dan susun atur kedai ialah perletakan dan penyusunan barangan, kelengkapan dan lekapan. Ianya amat berguna kepada sebuah kedai yang bersaiz kecil kerana ia memudahkan pelanggan melihat keseluruhan barangniaga dengan jelas. Menurut Levy [1] persekitaran kedai (rekabentuk dan susunatur) dan persembahan serta lokasi barangniaga dalam sesebuah kedai mempunyai kesan yang signifikan ke atas kelakuan membeli. Rekabentuk kedai akan menarik pelanggan mengunjungi lokasi kedai, meningkatkan masa keberadaan dalam kedai dan lantas meningkatkan jumlah pembelian pelanggan. Ini menjadi sebab kepada penyelidik untuk mengetahui persepsi pelajar terhadap rekabentuk kedai dan susun atur barangniaga di koperasi Polimas.

Koperasi Politeknik Sultan Abdul Halim Mu'adzam Shah (POLIMAS) ditubuhkan pada 10 Julai 1996 dengan nombor pendaftaran Koop Institusi No.43 dan telah menukarkan namanya kepada Koperasi Polimas Kedah Berhad melalui suatu pindaan undang-undang kecil pada hari didaftarkan di bawah seksyen 1S(3) Akta koperasi 1993. Koperasi Polimas ditandatangani dan dimeteraikan pada 4 November 1996. Undang- undang kecil koperasi polimas diluluskan dalam mesyuarat agung pada 30 Julai 1996 dan telah didaftarkan di bawah seksyeen 18(3) Akta Koperasi 1993. Koperasi polimas telah beroperasi selama 29 tahun di Politeknik Sultan Abdul Halim Mu'adzam Shah dan ditempatkan di dua lokasi yang berbeza iaitu berdekatan dengan foyer Dewan Kuliah 1 dan di kamsis pelajar. Ianya menjadi tumpuan warga POLIMAS amnya dan pelajar khususnya untuk mendapatkan barangan keperluan harian mereka. Antara barangniaga yang dijual ialah seperti alatan menulis, makanan dan minuman ringan, kelengkapan penjagaan diri, sabun membasuh dan sebagainya lagi. Pendek kata kewujudan koperasi banyak manfaatnya kepada warga POLIMAS itu sendiri terutamanya para pelajar yang tinggal di kamsis kerana mereka tidak mempunyai kenderaan untuk keluar membeli barang keperluan mereka di luar. Namun, dari temubual secara tidak langsung yang dijalankan terhadap 
sekumpulan pelajar didapati kebanyakan mereka tidak berpuashati dengan persekitaran dalaman koperasi tersebut terutamanya dari segi rekabentuk kedai dan susun atur barangniaga yang dikatakan berserabut dan berselerak. Justeru timbul minat penyelidik untuk mengetahui pandangan sebenar para pelajar terhadap reka bentuk kedai dan susun atur barang niaga di koperasi POLIMAS.

Mempunyai reka bentuk dan susun atur kedai yang menarik adalah penting untuk memaksimumkan pendapatan peruncit. Dengan merangka satu pelan, peruncit boleh mengarahkan pembeli secara strategik kepada produk berkeutamaan tinggi dan menjana jualan tak dirancang. Susun atur kedai yang berkesan juga menjadikan ruang lebih teratur dan pembeli mudah bergerak, yang mana ia penting untuk memberikan pengalaman beli-belah yang menarik. Seseorang pelanggan yang selesa dengan sesebuah kedai akan membeli lebih dari mereka yang tidak.

Penyelidik telah menggariskan 3 objektif utama kajian iaitu meninjau persepsi pelajar terhadap reka bentuk kedai dan susun atur barang niaga di koperasi Polimas. Kedua, mengenalpasti permasalahan yang dihadapi oleh pelajar dengan rekabentuk dan susunatur barangniaga sedia ada di koperasi Polimas. Seterusnya adalah mengenalpasti aspekaspek reka bentuk dan susunatur koperasi Polimas yang perlu dilakukan penambahbaikan.

\section{KAJIAN LITERATUR}

\subsection{Reka Bentuk Kedai}

Persekitaran, rekabentuk dan persembahan serta perletakan barangniaga dalam sesebuah kedai mempunyai impak yang besar ke atas gelagat pembelian pengguna. Rekabentuk kedai boleh menarik pelanggan datang ke kedai, meningkatkan masa yang diluangkan dalam kedai dan meningkatkan jumlah pembelian pelanggan. Rekabentuk kedai juga mempunyai kesan jangka panjang dalam membina kesetiaan pelanggan terhadap peruncit melalui peningkatan imej jenama peruncit dan menyediakan pengalaman membelibelah yang menyeronokkan lalu menggalakkan pelanggan untuk melakukan kunjungan semula ke kedai pada masa hadapan. Rekabentuk peruncitan merupakan cabang pemasaran dan dianggap sebahagian daripada jenama keseluruhan kedai. Elemen-elemen rekabentuk kedai seperti peragaan tingkap, lengkapan dan lekapan, pencahayaan, lantai, muzik dan susunatur kedai digunakan untuk mencipta jenama atau rayuan khusus. Untuk mendapatkan rekabentuk kedai yang baik, susunatur, tanda-tanda, dan barang yang dipamerkan perlu dirancang dengan teliti. Levy et al [1].

Rekabentuk dan susunatur kedai menyampaikan sejumlah besar maklumat mengenai peruncit kepada pengguna. Persekitaran dalaman kedai mesti menyumbang kepada objektif asas peruncitan untuk meminimumkan perbelanjaan operasi dan memaksimumkan kepuasan jualan dan kepuasan pelanggan, seterusnya keuntungan. Untuk mencapai matlamat ini, persekitaran dalaman kedai harus menarik, selesa dan memudahkan pelanggan. Ia juga harus membenarkan peruncit menggunakan ruang dalaman dengan cekap dan berkesan. Peruncit menggunakan susun atur untuk mempengaruhi tingkah laku pelanggan dengan merancang aliran kedai, penempatan barangan dan suasana. Susun atur juga membantu peruncit memahami berapa banyak pendapatan setiap kaki persegi yang dijana. Melalui maklumat ini, peruncit dapat menilai dengan baik kekuatan dan kelemahan strategi campuran barangniaga mereka. Justeru, reka bentuk mestilah selaras dan memperkuat strategi peruncit dengan memenuhi keperluan pasaran sasaran dan membina kelebihan daya saing yang mampan. Levy et al. [1] menggariskan 4 elemen utama dalam rekabentuk kedai iaitu susunatur, papan tanda dan grafik, kawasan jualan dan luaran kedai. Dalam kajian ini penyelidik hanya memberi tumpuan kepada susunatur dalaman dan luaran kedai sahaja.

\subsection{Susunatur kedai.}

Susun atur kedai ialah rekabentuk ruang lantai dan penempatan barang-barang di dalam sesebuah kedai. Susun atur kedai membantu mempengaruhi tingkah laku pelanggan, yang bermaksud apabila dilakukan dengan betul, ia merupakan strategi utama untuk kejayaan. Pemilik kedai memilih tempat terbaik untuk meletakkan barang dagangan mereka, dan ini membantu mereka merancang aliran pelanggan dan mencipta suasana tertentu di dalam kedai [2]. Peruncit menggunakan susun atur untuk mempengaruhi tingkah laku pelanggan dengan merancang aliran kedai, penempatan barangan dan atmosferik. Susun atur juga membantu peruncit memahami berapa banyak pendapatan setiap kaki persegi yang boleh dijana. Menggunakan maklumat ini, mereka dapat menilai dengan baik kekuatan dan kelemahan dalam campuran barangniaga mereka [3].

\subsection{Persepsi}

Persepsi didefinisikan sebagai proses di mana seseorang memilih, menyusun dan mentafsir rangsangan, di mana rangsangan ini kemudiannya ditapis dan disesuaikan untuk dijadikan pandangan sendiri terhadap sesuatu [4]. Walaupun didedahkan kepada perkara yang sama, dalam persekitaran yang 
sama, dua individu tidak mungkin berkongsi pengalaman yang sama [5]. Keseluruhan proses persepsi berlaku dalam tiga tahap iaitu tahap pendedahan, tahap perhatian dan tahap pentafsiran. Otak manusia hanya menerima rangsangan di tahap perhatian dan mentafsir rangsangan berpandukan kepada pengalaman lepas dan hasrat dalam tahap pentafsiran. Akhirnya ketiga-tiga tahap ini membentuk persepsi. Apabila seseorang peruncit mengetahui persepsi pelanggan terhadap perniagaan, produk dan perkhidmatannya, peruncit akan mengetahui sama ada perniagaannya berada pada landasan yang betul atau sebaliknya. Semua interaksi yang berlaku antara pelanggan dan peruncit akhirnya akan mempengaruhi pandangan pelanggan dan imej peruncit [6].

\subsection{Sikap}

Sikap adalah komposit pengguna dari (1) kepercayaan tentang, (2) perasaan tentang, (3) dan niat tingkah laku terhadap sesuatu objek - dalam konteks pemasaran, biasanya terhadap jenama atau kedai. Komponen ini perlu dilihat secara bersama kerana mereka sangat saling bergantung dan bersama-sama mewakili kuasa yang mempengaruhi bagaimana pengguna akan bertindak balas terhadap objek tersebut. [7]

\section{METODOLOGI}

Sebanyak 150 orang pelajar POLIMAS telah dipilih secara rawak melalui kaedah persampelan mudah. Penyelidik menggunakan kaedah penetapan saiz sampel berdasarkan pendekatan konvensional iaitu purata saiz sampel berdasarkan kajian-kajian terdahulu. Kaedah ini dipilih kerana ianya mudah, murah dan mewakili. Responden terdiri dari pelajar-pelajar yang pernah mengunjungi koperasi POLIMAS untuk melakukan pembelian. Kaedah penyelidikan yang digunakan dalam kajian ialah deskriptif iaitu suatu kajian yang bertujuan untuk menerangkan sesuatu fenomena yang sedang berlaku. Kaedah pengumpulan data primer yang digunakan ialah kaedah tinjauan. Untuk itu penyelidik telah mereka bentuk borang soal-selidik yang mengandungi sejumlah 50 buah soalan yang berkaitan objektif kajian. Prosedur Cronbach' Alpha coefficient di gunakan untuk mengukur darjah kebolehpercayaan instrumen, dan nilai skala yang di perolehi adalah 0.89. Ini menunjukkan tahap kesesuaian item-item di dalam borang soal-selidik ini adalah baik. Penyelidik turut menggunakan data sekunder sebagai bahan rujukan seperti jurnal, artikel dan buku rujukan. Data-data dan maklumat yang dikumpul daripada soal selidik dalam kajian ini akan dianalisis secara kuantitatif menggunakan program SPSS version 23. Statistik deskriptif dan frekuensi digunakan untuk menguji pembolehubahpembolehubah kajian.

\subsection{Analisis dan Perbincangan}

\section{Bahagian A : Latar belakang responden}

Jadual 1 :-Ringkasan Taburan Demografik Responden.

\begin{tabular}{|c|c|c|c|c|}
\hline No & Soalan & & Kekerapan (orang) & Peratus (\%) \\
\hline 1. & Jantina & $\begin{array}{l}\text { Lelaki } \\
\text { Perempuan } \\
\text { Jumlah }\end{array}$ & $\begin{array}{c}49 \\
101 \\
150\end{array}$ & $\begin{array}{c}33 \\
67 \\
100 \\
\end{array}$ \\
\hline 2. & Umur & $\begin{array}{l}18 \text { tahun kebawah } \\
19-21 \text { tahun } \\
22-24 \text { tahun } \\
25 \text { tahun keatas } \\
\text { Jumlah }\end{array}$ & $\begin{array}{c}6 \\
113 \\
28 \\
3 \\
150 \\
\end{array}$ & $\begin{array}{c}4 \\
75 \\
19 \\
2 \\
\mathbf{1 0 0} \\
\end{array}$ \\
\hline 3. & Bangsa & $\begin{array}{l}\text { Melayu } \\
\text { Cina } \\
\text { India } \\
\text { Lain-lain } \\
\text { Jumlah } \\
\end{array}$ & $\begin{array}{c}104 \\
20 \\
24 \\
2 \\
\mathbf{1 5 0}\end{array}$ & $\begin{array}{c}69 \\
13 \\
16 \\
2 \\
\mathbf{1 0 0}\end{array}$ \\
\hline 4. & Jabatan & $\begin{array}{l}\text { Jabatan Kejuruteraan Awam } \\
\text { (JKA) } \\
\text { Jabatan Kejuruteraan Elektrik } \\
\text { (JKE) } \\
\text { Jabatan Kejuruteraan Mekanikal } \\
\text { (JKM) } \\
\text { Jabatan Perdagangan (JP) } \\
\text { Jumlah }\end{array}$ & $\begin{array}{c}14 \\
2 \\
2 \\
132 \\
150\end{array}$ & $\begin{array}{c}9 \\
1.5 \\
1.5 \\
88 \\
\mathbf{1 0 0}\end{array}$ \\
\hline
\end{tabular}


Norazlizah/ International Journal of Business and Management, 4(4) 2020, Pages: 09-17

\begin{tabular}{|c|c|c|c|c|}
\hline 5. & $\begin{array}{l}\text { Pernah membeli di } \\
\text { koperasi polimas }\end{array}$ & $\begin{array}{l}\text { Ya } \\
\text { Tidak } \\
\text { Jumlah }\end{array}$ & $\begin{array}{c}140 \\
10 \\
150\end{array}$ & $\begin{array}{c}93 \\
7 \\
\mathbf{1 0 0}\end{array}$ \\
\hline 6. & $\begin{array}{l}\text { Lokasi koperasi } \\
\text { yang pernah ada } \\
\text { kunjungi. }\end{array}$ & $\begin{array}{l}\text { Kamsis } \\
\text { Depan perpustakaan } \\
\text { Jumlah }\end{array}$ & $\begin{array}{c}13 \\
137 \\
\mathbf{1 5 0}\end{array}$ & $\begin{array}{c}9 \\
91 \\
\mathbf{1 0 0}\end{array}$ \\
\hline 7. & $\begin{array}{l}\text { Kekerapan } \\
\text { mengunjungi } \\
\text { dalam seminggu }\end{array}$ & $\begin{array}{l}\text { Tidak pernah } \\
3 \text { kali seminggu } \\
2 \text { kali seminggu } \\
\text { Setiap hari } \\
\text { Jumlah } \\
\end{array}$ & $\begin{array}{c}9 \\
51 \\
37 \\
53 \\
\mathbf{1 5 0} \\
\end{array}$ & $\begin{array}{c}6 \\
34 \\
25 \\
35 \\
\mathbf{1 0 0}\end{array}$ \\
\hline 8. & Sebab kunjungi & $\begin{array}{l}\text { Beli barangan keperluan diri } \\
\text { Beli alat tulis } \\
\text { Beli makanan/minuman } \\
\text { Perkhidmatan fotokopi } \\
\text { Lain-lain } \\
\text { Jumlah }\end{array}$ & $\begin{array}{c}10 \\
11 \\
88 \\
24 \\
17 \\
\mathbf{1 5 0}\end{array}$ & $\begin{array}{c}7 \\
7 \\
59 \\
16 \\
11 \\
\mathbf{1 0 0}\end{array}$ \\
\hline
\end{tabular}

Berdasarkan jadual di atas pelajar lelaki yang terlibat sebagai responden dalam kajian ini adalah seramai 49 orang $(33.0 \%)$ dan pelajar perempuan adalah pula seramai 101 orang (67.0\%). Kebanyakan responden adalah dalam lingkungan umur 19-21 tahun. Manakala bagi kategori bangsa pula seramai 104 orang responden adalah bangsa Melayu, 20 orang berbangsa Cina, 24 orang berbangsa India dan baki 2 orang dari lain-lain bangsa. Daripada 150 orang pelajar yang terlibat sejumlah 14 orang $(9 \%)$ adalah dari JKA , 2 orang $(1.5 \%)$ dari JKE, 2 orang $(1.5 \%)$ dari JKM dan selebihnya seramai 132 orang $(88.0 \%)$ dari JP. Berkaitan dengan pengalaman responden dengan Koperasi Polimas, ternyata majoriti pelajar pernah membeli di Koperasi Polimas dengan peratusan kekerapan 93\% (140 orang) dan lokasi Koperasi yang paling kerap dikunjungi pelajar ialah di depan perpustakaan dengan peratus kekerapan 91\%(137 orang). Jadual di atas juga menunjukkan kekerapan berkunjung ke Koperasi dalam masa seminggu ialah setiap hari dengan peratusan kekerapan 35\% (53 orang) diikuti 3 kali seminggu dengan peratus kekerapan 34\%(51 orang) dan dua kali seminggu dengan peratus kekerapan $25 \%$ (37 orang). Ini menunjukkan bahawa majoriti pelajar kerap mengunjungi Koperasi Polimas dalam masa seminggu. Antara sebab kunjungan yang tertinggi ialah untuk membeli makanan dan minuman sebanyak 59\%(88 orang), diikuti dengan untuk mendapatkan perkhidmatan fotokopi sebanyak $16 \%$ (24 orang) dan lain-lain tujuan sebanyak $11 \%$ (17 orang).

\section{Bahagian B: Pandangan responden terhadap reka bentuk dan susun atur barangniaga di Koperasi Polimas.}

Jadual 2: Pandangan responden terhadap reka bentuk dan susun atur barangan niaga di koperasi Polimas.

\begin{tabular}{|l|l|c|c|c|}
\hline & & Peratusan Setuju & $\begin{array}{c}\text { Skor } \\
\text { Purata }\end{array}$ & Sisihan Piawai \\
\hline 1. & $\begin{array}{l}\text { Susun atur dalaman kedai memudahkan } \\
\text { pergerakan }\end{array}$ & 64 & 2.67 & 0.73 \\
\hline 2. & $\begin{array}{l}\text { Susun atur dalaman kedai memudahkan saya } \\
\text { untuk membuat pilihan barangan }\end{array}$ & 64 & 2.67 & 0.70 \\
\hline 3. & $\begin{array}{l}\text { Susun atur dalaman kedai amat menarik } \\
\text { perhatian }\end{array}$ & 47 & 2.46 & 0.74 \\
\hline 4. & $\begin{array}{l}\text { Susun atur barangniaga mendorong saya untuk } \\
\text { membuat pembelian }\end{array}$ & 53 & 2.57 & 0.73 \\
\hline 5. & $\begin{array}{l}\text { Susun atur barangniaga memudahkan saya } \\
\text { membuat pencarian }\end{array}$ & 59 & 2.67 & 0.79 \\
\hline 6. & $\begin{array}{l}\text { Rekabentuk luaran koperasi menarik minat saya } \\
\text { untuk masuk ke dalam kedai }\end{array}$ & 51 & 2.49 & 0.73 \\
\hline 7. & Papan tanda koperasi amat jelas dan menarik & 57 & 2.60 & 0.75 \\
\hline
\end{tabular}


Norazlizah/ International Journal of Business and Management, 4(4) 2020, Pages: 09-17

\begin{tabular}{|c|c|c|c|c|}
\hline 8. & Persekitaran dalaman kedai sangat bersih & 66 & 274 & 074 \\
\hline 9. & $\begin{array}{l}\text { Peragaan barangan di atas rak amat menarik } \\
\text { perhatian }\end{array}$ & 54 & 2.60 & 0.77 \\
\hline 10. & Dekorasi dalaman kedai amat kreatif dan cantik & 46 & 2.45 & 0.77 \\
\hline 11. & Semua barangan di letakkan tanda harga & 53 & 2.53 & 0.82 \\
\hline 12. & $\begin{array}{l}\text { Saya berpuas hati dengan rekabentuk dan } \\
\text { susunatur }\end{array}$ & 56 & 2.63 & 0.80 \\
\hline 13. & $\begin{array}{l}\text { Saya suka untuk membuat pembelian di koperasi } \\
\text { Polimas }\end{array}$ & 64 & 2.73 & 0.78 \\
\hline \multirow[t]{2}{*}{14.} & $\begin{array}{l}\text { Saya akan terus mengujungi koperasi untuk } \\
\text { membeli-belah }\end{array}$ & 63 & 2.71 & 0.81 \\
\hline & PURATA & 56.93 & 2.61 & 0.76 \\
\hline
\end{tabular}

Jadual 2 di atas pula menunjukkan pandangan responden terhadap reka bentuk dan susun atur barangniaga di Koperasi Polimas. Secara purata responden bersetuju dengan rekabentuk dan susunatur barangniaga di dalam Koperasi Polimas. Namun peratusan setuju hanya $56.93 \%$ atau 85 orang sahaja dengan nilai skor purata 2.61 iaitu pada skor 3 iaitu skala setuju dan nilai sisihan piawai hanya 0.76 yang menunjukkan serakan data yang kecil dan tidak pelbagai kerana rata-rata responden memberikan jawapan yang hampir sama. Peratusan setuju untuk setiap item adalah dalam julat $51 \%$ ke $66 \%$ sahaja. Manakala sebanyak $47 \%$ responden sahaja yang bersetuju tentang item ke 3 iaitu susun atur dalaman kedai amat menarik perhatian. Untuk item ke 10 berkenaan dekorasi dalaman kedai amat kreatif dan cantik, kadar persetujuan responden hanya $46 \%$. Ini menunjukkan kebanyakan pelajar Polimas kurang menyukai susunatur dalaman kedai kerana bagi mereka ianya kurang menarik perhatian, kurang kreatif dan cantik. Item ke 8 yang berkaitan dengan kebersihan persekitaran dalaman koperasi meraih kadar peratusan tertinggi iaitu sebanyak $66 \%$ berbanding item-item lain.

\section{Bahagian C: Permasalahan yang dihadapi oleh pelajar semasa membeli di koperasi Polimas}

Jadual 3: Permasalahan yang dihadapi oleh pelajar semasa membeli di koperasi Polimas.

\begin{tabular}{|c|c|c|c|c|}
\hline & & Peratusan Setuju & Skor Purata & Sisihan Piawai \\
\hline 1. & Barangan yang diperlukan sukar dicari & 67 & 2.77 & 0.77 \\
\hline 2. & $\begin{array}{l}\text { Jarak antara rak peragaan sangat sempit hingga } \\
\text { menyukarkan pergerakan. }\end{array}$ & 66 & 2.77 & 0.81 \\
\hline 3. & $\begin{array}{l}\text { Barang niaga sentiasa kehabisan stok bila } \\
\text { diperlukan. }\end{array}$ & 65 & 2.79 & 0.80 \\
\hline 4. & Suasana dalaman tidak selesa dan merimaskan. & 56 & 2.67 & 0.79 \\
\hline 5. & $\begin{array}{l}\text { Ruang legar yang sempit menyebabkan berlaku } \\
\text { kesesakan dalam kedai pada waktu puncak. }\end{array}$ & 72 & 2.93 & 0.79 \\
\hline 6. & Rak dan barangan berhabuk & 54 & 2.63 & 0.75 \\
\hline 7. & $\begin{array}{l}\text { Barangan di dalam kedai tidak tersusun dan } \\
\text { berterabur. }\end{array}$ & 48 & 2.59 & 0.80 \\
\hline 8. & Tanda harga tidak dipamerkan & 61 & 2.75 & 0.79 \\
\hline 9. & $\begin{array}{l}\text { Kaunter bayaran tidak mencukupi hingga } \\
\text { terpaksa beratur panjang untuk membayar. }\end{array}$ & 78 & 3.07 & 0.79 \\
\hline 10. & $\begin{array}{l}\text { Kedudukan kaunter bayaran terlalu dekat dengan } \\
\text { pintu masuk utama }\end{array}$ & 76 & 3.07 & 0.84 \\
\hline & PURATA & 64 & 2.80 & 0.79 \\
\hline
\end{tabular}


Jadual 3 pula menunjukkan analisa tentang permasalahan yang dihadapi oleh pelajar semasa membeli di Koperasi Polimas. Purata setuju pelajar untuk kesemua item yang disoal ialah $64 \%$ dengan skor purata 2.8 iaitu pada skala 3 (setuju) dan nilai sisihan piawai 0.79 yang menunjukkan serakan data yang kecil dan tidak pelbagai. Antara permasalahan utama yang melanda para pelajar ialah berkaitan kaunter bayaran. Seramai $78 \%$ pelajar bersetuju bahawa kaunter bayaran tidak mencukupi hingga terpaksa beratur panjang untuk membayar manakala $76 \%$ pelajar bersetuju tentang kedudukan kaunter bayaran yang terlalu dekat dengan pintu masuk utama. Ini menjadikan pintu masuk utama koperasi sesak dengan pelajar yang beratur untuk membayar. Ruang legar yang sempit juga menyebabkan berlaku kesesakan dalam kedai pada waktu puncak dan ini dibuktikan dengan peratusan setuju untuk item 5 adalah sebanyak $72 \%$. Seramai $67 \%$ responden turut bersetuju dengan barangan yang diperlukan sukar dicari, $66 \%$ pula bersetuju bahawa jarak antara rak peragaan sangat sempit hingga menyukarkan pergerakan dan $65 \%$ responden pula bersetuju bahawa barang niaga sentiasa kehabisan stok bila diperlukan. $61 \%$ responden pula bersetuju bahawa tanda harga tidak dipamerkan. Penyelidik merasakan perkara-perkara ini perlu diambil perhatian oleh pihak pengurusan Koperasi Polimas dalam meningkatkan mutu perkhidmatan di koperasi.

\section{BAHAGIAN D : Perkara yang boleh mempengaruhi anda untuk melakukan pembelian.}

Jadual 3: Perkara yang boleh mempengaruhi anda untuk melakukan pembelian.

\begin{tabular}{|c|c|c|c|c|}
\hline & Faktor Keselamatan Dan Privasi & $\begin{array}{l}\text { Peratusan } \\
\text { Setuju }\end{array}$ & Skor Purata & Sisihan Piawai \\
\hline 1. & $\begin{array}{l}\text { Dekorasi dalaman sesebuah } \\
\text { kedai. }\end{array}$ & 67 & 2.78 & 0.83 \\
\hline 2. & $\begin{array}{l}\text { Susun atur barangan yang } \\
\text { menarik. }\end{array}$ & 67 & 2.85 & 0.79 \\
\hline 3. & $\begin{array}{l}\text { Saya melakukan pembelian } \\
\text { kerana tertarik persekitaran } \\
\text { dalaman yang bersih, kemas dan } \\
\text { selesa. }\end{array}$ & 61 & 2.70 & 0.82 \\
\hline 4. & $\begin{array}{l}\text { Peragaan barangniaga amat } \\
\text { mempengaruhi pembelian saya. }\end{array}$ & 61 & 2.76 & 0.85 \\
\hline 5. & $\begin{array}{l}\text { Layanan yang baik dari jurujual } \\
\text { mempengaruhi saya untuk } \\
\text { melakukan pembelian. }\end{array}$ & 58 & 2.64 & 0.97 \\
\hline 6. & $\begin{array}{l}\text { Imej kedai sangat mempengaruhi } \\
\text { saya dalam melakukan } \\
\text { pembelian. }\end{array}$ & 61 & 2.72 & 0.83 \\
\hline 7. & $\begin{array}{l}\text { Promosi dalam kedai amat } \\
\text { mempengaruhi saya dalam } \\
\text { melakukan pembelian. }\end{array}$ & 57 & 2.65 & 0.89 \\
\hline & PURATA & 62 & 2.73 & 0.85 \\
\hline
\end{tabular}

Analisa seterusnya adalah berkaitan perkara yang boleh mempengaruhi responden untuk melakukan pembelian. Purata peratusan setuju untuk semua item di bahagian ini ialah $62 \%$ dengan skor purata 2.73 iaitu pada skala 3 (setuju) dan nilai sisihan piawai 0.85 yang juga menunjukkan serakan data yang kecil dan tidak pelbagai. Peratusan setuju tertinggi adalah pada item pertama dan kedua iaitu berkaitan dekorasi dalaman sesebuah kedai dan susun atur barangan yang menarik yang boleh mempengaruhi responden untuk melakukan pembelian dengan peratusan setuju masing-masing sebanyak 67\% (100 orang). Diikuti dengan item ke 3: melakukan pembelian kerana tertarik dengan persekitaran dalaman yang bersih, kemas dan selesa, item ke 4: peragaan barangniaga amat mempengaruhi pembelian saya dan item ke $6:$ imej kedai sangat mempengaruhi saya dalam melakukan 
pembelian dengan peratusan setuju untuk ketiga-tiga item tersebut ialah sebanyak 61\% (92 orang). Perkara-perkara lain yang turut boleh mempengaruhi pembelian responden ialah layanan jurujual dan promosi yang diadakan iaitu masingmasing dengan peratusan setuju sebanyak $58 \%(87$ orang) dan $57 \%$ (86 orang). Analisa ini menunjukkan betapa pentingnya rekabentuk dan susunatur kedai dalam mempengaruhi pembelian pelanggan. Secara amnya, peruncit perlu berusaha menjual produk yang dapat memenuhi keperluan pengguna dan menyediakan susunatur kedai yang membenarkan pelanggan bergerak bebas untuk membeli lebih banyak barangniaga daripada yang dirancang [1].

\section{BAHAGIAN E : Aspek-aspek rekabentuk dan susunatur barangniaga koperasi yang perlu dilakukan penambahbaikan.}

Jadual 4: Aspek-aspek rekabentuk dan susunatur barangniaga koperasi yang perlu dilakukan penambahbaikan.

\begin{tabular}{|c|c|c|c|c|}
\hline & & $\begin{array}{c}\text { Peratusan } \\
\text { setuju }\end{array}$ & $\begin{array}{l}\text { Skor } \\
\text { Purata } \\
\end{array}$ & Sisihan Piawai \\
\hline 1. & Penambahan rak barangan & 88 & 3.30 & 0.76 \\
\hline 2. & Meluaskan ruang legar & 90 & 3.41 & 0.68 \\
\hline 3. & Persekitaran yang bersih & 51 & 3.40 & 0.63 \\
\hline 4. & $\begin{array}{l}\text { Susunan barang mengikut } \\
\text { label }\end{array}$ & 91 & 3.40 & 0.66 \\
\hline 5. & Meletakkan label harga & 91 & 3.40 & 0.69 \\
\hline 6. & Peragaan barangan atas rak & 90 & 3.36 & 0.69 \\
\hline 7. & Dekorasi dalaman kedai & 88 & 3.32 & 0.74 \\
\hline 8. & Dekorasi luaran kedai & 87 & 3.32 & 0.74 \\
\hline 9. & Kaunter bayaran yang lebih & 90 & 3.41 & 0.68 \\
\hline & PURATA & 86 & 3.39 & 0.69 \\
\hline
\end{tabular}

Analisis yang terakhir ialah berkaitan aspek-aspek reka bentuk dan susun atur barangniaga koperasi yang perlu dilakukan penambahbaikan. Purata peratusan setuju untuk semua item di bahagian ini ialah $86 \%$ dengan skor purata 3.39 iaitu pada skala 3(setuju) dan nilai sisihan piawai 0.69 yang juga menunjukkan serakan data yang kecil dan tidak pelbagai. Berdasarkan jadual 4 di atas skor tertinggi ialah item ke 4 dan ke 5 iaitu tentang susunan barang perlu mengikut label dan barangniaga yang diperagakan perlu diletakkan label harga dengan peratusan responden yang mengatakan ianya perlu ialah sebanyak 91\%. Aspek kedua yang perlu dilakukan penambahbaikan ialah meluaskan ruang legar, peragaan barangan atas rak dan menyediakan lebih banyak kaunter bayaran dengan peratusan sebanyak 90\%. Penambahan rak barangan turut perlu dilakukan penambahbaikan kerana peratusan responden yang merasakan ianya perlu adalah sebanyak $88 \%$. Begitu juga dengan dekorasi dalaman (item 7) dan luaran (item 8) koperasi di mana $87 \%$ dan lebih responden memilih ianya perlu dilakukan penambahbaikan.

\section{KESIMPULAN}

Penemuan yang dikaitkan dengan objektif pertama kajian iaitu meninjau persepsi pelajar terhadap reka bentuk kedai dan susun atur barang niaga di koperasi Polimas. Didapati kebanyakan pelajar Polimas kurang menyukai susunatur dalaman kedai kerana bagi mereka ianya kurang menarik perhatian, kurang kreatif dan cantik. Peruncit harus berusaha menjual produk yang memuaskan keperluan pembeli dan menyediakan persekitaran kedai yang menarik serta 
memudahkan pelanggan untuk bergerak di sekitar kedai dan membeli lebih daripada yang dirancang. Perlu diingatkan bahawa penjualan hanya berlaku apabila pembelian sebenar telah lengkap dan peruncit harus terus membina sikap positif pembeli terhadap kedai mereka pada setiap masa, walaupun selepas jualan. Ia juga boleh meningkatkan kadar pengekalan pelanggan yang membawa kepada peningkatan keuntungan dan kesetiaan terhadap peruncit [9]. Idea keseluruhan peruncit adalah untuk menukarkan pelawat kepada pembeli dan pembeli kepada pelanggan setia. Kajian lepas mendapati $70 \%$ keputusan pembelian dilakukan di dalam kedai dan keperluan boleh dicipta melalui rekabentuk kedai dan peragaan barangniaga [10].

Penemuan seterusnya ialah berkaitan objektif kajian yang kedua iaitu mengenalpasti permasalahan yang dihadapi oleh pelajar semasa membeli di Koperasi Polimas. Antara masalah yang dikenalpasti ialah kaunter bayaran tidak mencukupi, kedudukan kaunter bayaran yang tidak strategik kerana terlalu dekat dengan pintu masuk utama, ruang legar yang sempit dan jarak antara rak peragaan juga sempit hingga menyukarkan pergerakan. Semua masalah ini jika dilihat berkait rapat dengan rekabentuk dan susunatur kedai. Geetha et al. [11] telah melakukan kajian dan mendapati persekitaran kedai bukan hanya membawa kepada pembelian tak dirancang malahan pencarian kepelbagaian. Pencarian kepelbagaian boleh meningkatkan saiz pembelian [12], justeru dengan melabur untuk persekitaran kedai peruncit berharap untuk mendapatkan jualan yang lebih tinggi. Tambahan pula, apabila pencarian kepelbagaian berlaku, jenama yang tidak dominan turut menikmati pulangan atas perbelanjaan jenama yang dominan [13-14]. Kajian yang dilakukan oleh Devi Prasad [15] telah menggariskan tiga faktor utama rekabentuk dan susunatur kedai iaitu lekapan dan lengkapan, pintu keluar dan kemudahan pergerakan dalam kedai. Beliau membuat kesimpulan bahawa jika rekabentuk dan susunatur kedai berada pada tahap yang baik maka tahap pengalaman membeli-belah pelanggan juga akan meningkat.

Penemuan terakhir adalah mengenai aspek-aspek rekabentuk dan susunatur koperasi Polimas yang perlu dilakukan penambahbaikan. Rata-rata pelajar bersetuju dengan aspek-aspek penambahbaikan yang dicadangkan di mana aspek susunan dan pelabelan barangniaga mendominasi pilihan responden, diikuti aspek peragaan dan peruntukan ruang, dan yang terakhir aspek dekorasi dalaman dan luaran kedai. Ditanya mengenai faktor yang boleh mempengaruhi mereka dalam melakukan pembelian, ternyata kebanyakannya memilih dekorasi dalaman sesebuah kedai dan susun atur barangan yang menarik sebagai pengaruh yang utama. Diikuti dengan faktor persekitaran dalaman yang bersih, kemas dan selesa. Justeru, pihak pengurusan koperasi perlu mempertimbangkan idea ini memandangkan impaknya ke atas perlakuan pembelian amat tinggi. Impak persekitaran kedai ke atas kecenderungan perlakuan boleh memotivasi perlakuan tertentu seperti keinginan untuk berada dalam kedai, memerhati dan meninjau persekitaran serta berkomunikasi dengan orang lain di persekitaran yang sama, sebaliknya persekitaran yang tidak baik boleh membawa kepada tingkah laku mengelak atau keluar dari kedai [16]. Para peruncit mendakwa mereka mempengaruhi perlakuan pembelian pengguna dengan memanipulasi persekitaran kedai melalui susunatur, warna, pencahayaan dan muzik [17]. Menurut Priyanka [17] pelanggan akan memberi tumpuan khusus kepada rekabentuk sesebuah kedai, termasuklah susunatur yang bersesuaian, dekorasi dalaman yang menarik, papan tanda dan logo yang jelas, peragaan barangniaga di kaki lima kedai, maklumat dan pengelasan barangniaga yang mencukupi dan memudahkan.

Kesimpulan yang dapat dibuat dari kajian ini ialah adalah lebih baik untuk merangsang dan menggembirakan pelanggan di dalam persekitaran kedai sehingga ke tahap di mana ianya boleh meningkatkan pembelian tak dirancang. Rekabentuk dan susunatur kedai merupakan faktor penting yang mempengruhi perluan pembelian dan pembentukan imej kedai. Mengambil pendekatan yang lebih strategik dalam merekabentuk kedai boleh mendatangkan pulangan yang lebih besar kepada peruncit melalui peningkatan jualan, kesetiaan pelanggan dan keuntungan. Walau bagaimanapun kajian ini hanya memfokus kepada persepsi dan sikap pelajar terhadap rekabentuk dan susunatur kedai. Dicadangkan pada masa hadapan kajian yang sama dilakukan tetapi memfokus kepada impaknya ke atas kepuasan pelanggan ataupun jualan.Although Malaysia is already ranked high globally for its healthcare services, demand for more advanced slimming treatment technologies seems has yet to catch up. Due to modern lifestyle and increasing rate of overweight and obesity in Malaysia, there is a high possibility that the market opportunity for slimming centre will be growing within the next few years. The target market for slimming centre is more streamlined to those career women with stable income who need to spend time to rest but at the same time preferred to be personally treated to reduce their body weight and reshape their body figure. In line with this, the slimming centre is a most suitable place where the consumers can pampered themselves in a relaxing spa environment and obtaining the desired body figure without too much hassle because almost every treatments will be using slimming technology innovations with assistance from the therapist. In line with the increasing number of women in the workforce, there 
is high chance for the slimming centre to sustain in the market. The availability of slimming centre is somehow empowering women to develop the socioeconomic stability.

\section{RUJUKAN}

[1] Levy, M., Barton A.W., \& Grewal, D .(2019). Retail Management 10th ed. New York: Mc Graw Hill Education.

[2] Heap, D. (January 21,2014). Store Layout and Customer Flow- Does It Matter For SMBs. Dimuat turun daripada https://www.signs.com/blog/storelayout-and-customer-flow-does-it-matter-for-smbs/ [3] Mate, B (September 26, 2017). The Importance Of Store Layout. Dimuat turun daripada https://bizfluent.com/about-6748117-importancestore-layout.html

[4] Plesis, P. J. D., \& Rousseau, D. (2003) : Buyer Behavior A Multi-Cultural Approach, 3rd ed., Oxford University Press Southern Africa.

[5] Schiffman, L., \& Kanuk, L. (2007). Consumer Behavior, 9th Edition. Upper Saddle River: Prentice-Hall.

[6] Waja, N. (November 2013) The Impact Of Store Image On Customer Perception. (Unpublished degree thesis) Department Of Industrial Psychology, University Of The Western Cape.

[7] Perner, L. (2018). Attitudes. Dimuat turun daripada

https://www.consumerpsychologist.com/cb_Attitud es.html

[8] Malhotra, N. K. (2010). Marketing research: An Applied Orientation 6th ed. New Jersey: Prentice Hall

[9] Chate, A. B (2012). Impact of Retail Store Design and Layout on Consumer's Mind (Unpublished master's thesis) AIMS Institute Of Management Studies, Pune.

[10] Essays, UK. (November 2018). Impact And Influence Of Store Design Customer Behaviour.
Dimuat turun daripada https://www.ukessays.com/essays/marketing/impac t-and-influence-of-store-design-customerbehaviour-marketing-essay.php?vref=1

[11] Geetha, M., Sivakumaran .B.,\& Sharma, P.(2010). Role Of Store Image In Consumer Impulse Buying Behavior. In: Advances in Consumer Research. Provo, UT: Association for Consumer Research 11, 194.

[12] Simonson, I.(1990). The Effect Of Purchase Quantity And Timing On Variety-Seeking Behavior. Journal of Marketing Research. 27 (2), 150-162

[13] Feinberg, F.M., Kahn, B.E., McAlister L (1992). Market Share Response When Consumers Seek Variety. Journal of Marketing Research, 227237.

[14] Sivakumaran, B., \& Shankar, V. (2010) The Moderating Role Of Variety Seeking In Order Of Entry Effect. Working paper, Great Lakes Institute of Management.

[15] Kotni, V.V. D. P. (2016), Impact of Store Layout Design on Customer Shopping Experience: A Study of FMCG Retail Outlets in Hyderabad, India, Proceedings of Annual Australian Business and Social Science Research Conference 26 - 27 September Crowne Plaza Hotel, Gold Coast, Queensland, Australia

[16] Abdul, J. N. A., Fikrya, A., \& Zainuddin, A.( 2016 ): The Impact of Store Atmospherics, Perceived Value, and Customer Satisfaction on Behavioural Intention, Fifth International Conference On Marketing And Retailing (5th Incomar) 2015. Procedia Economics and Finance 37 $538-544$

[17] Singh, P., Katiyar, N., \& Verma, G. (August 2014). Retail Shoppability: The Impact Of Store Atmospherics \& Store Layout On Consumer Buying Patterns, International Journal Of Scientific \& Technology Research Volume 3, Issue 8. 